Lucania seems well adapted for the narrow confines of an aquarium on account of its small size. When several are placed in a tank they at first swim about in a more or less compact school, but when they become accustomed to their surroundings, scatter about the tank. They are moderately active and swim and take their food indifferently at the surface, at the bottom or in mid water. They have more poise than Fundulus diaphanus or heteroclitus, are less inclined to sluggishness or excitability. They show good spirit, frequently chasing one another, but are not bad fighters.

In February, 1916, Mr. J. Taubles of New York succeeded in getting spawn from four Lucania parva, recently obtained from the writer. On March 15, I visited his establishment and was shown several healthy-looking fry about $1 / 4 \mathrm{in}$. in total length including caudal. They resembled the adults but were proportionately more slender with larger caudal fins. These he estimated to be three weeks old.

The fish had spawned and earlier fry hatched in a $14 \times 9 \times 9$ inch tank placed in a window with water temperature fairly uniform at perhaps 64 degrees, and depth of water about $6 \mathrm{in}$. The tank had a good growth of water plants, much fine vegetation, plentiful algae. Although precise records had not been kept, I obtained the following opinion from those who had kept and cared for the fish. Younger fry than those referred to above hatched March 9 from spawn deposited on February 24, a period of just two weeks.

$$
\begin{aligned}
& \text { J. T. Nichols, } \\
& \text { New York, N. Y. }
\end{aligned}
$$

\title{
FISH RECORDS FROM ORIENT, LONG ISLAND.
}

The following records refer to fishes taken near Orient, Long Island, New York. All the specimens referred to were collected by the writer and with the 
exception of the Siphostoma have recently been identified at the American Museum of Natural History. Some of the species mentioned are common, but the dates of occurrence given are of interest.

Round Herring Etrumeus sadina. Of less regular occurrence than Clupea harengus, although more or less common every summer, May to October. It was unusually abundant in 1915, as many as ten barrels being taken in one lift of fishing pounds during June, July, August and September. It is called spearing and sardine, and not differentiated by some fishermen from the common herring.

Common Anchovy. Stolephorus mitchilli. A specimen 3 in. total length. Sound. Nov. 4, 1915.

Pipefish, Siphostoma fuscum. Two taken in Long Island Sound, March 1, 1916.

Northern Barracuda, Sphyraena borealis. A specimen 10 in. total length was taken in the Sound, November 6, 1915.

Scad. Decapterus punctatus. A specimen 5\% in. total length. Sound. October 28.

Goggle-eyed Scad. Trachurops crumenophthalmus. A specimen $5 \frac{3 / 4}{1}$. total length. Sound. October 18, 1915.

Big-eye. Pricanthus arenatus. 'Two specimens $3^{1 / 4}$ and 4 in. total length. Sound. October 10 and 21, 1914. A few (all about this size) are taken every fall, September to November. The two specimens referred to have well developed preopercular spines.

Filefish. Monacanthus hispidus. A specimen $3^{1 / 2}$ in. total length. Sound. November 8, 1915.

Mitchill's Sculpin. Myoxocephalus mitchilli. A specimen $4^{1 / 2}$ in. total length. Bay. April 14, 1916.

Lump fish. Cyclopterus lumpus. A specimen two inches total length. Sound. October 25, 1914. We get a few of this species, usually about 3 in. long, every season, although it is never common. 
Naked Goby. Gobiosoma bosci. A specimen $1^{1 / 4}$ in. total length. Orient Bay. October 30, 1914.

Rock Eel. Pholis gunnellus. A specimen $3^{1 / 2}$ in. total length. Sound. November 15, 1915.

\section{Roy Latham, Orient, N. Y.}

[Mr. Latham's dried specimen identified as $\boldsymbol{M} y$ oxocephalus mitchilli differs from specimens of aeneus strikingly in color, being darker, the dark and white more contrasted, the fins more boldly marked. The ventral fins especially have three or four very bold black cross-bands, broader than the white interspaces, whereas in aeneus they are but faintly marked. The back seems to have been less elevated than in aeneus and the spinous dorsal is more elevated, especially posteriorly, its longest spines equal 1/2 head. Evidently this is the form described by De Kay as mitchilli (Cuvier \& Valenciennes), (New York Fauna, Fishes 1842), and presumedly scorpio (Mitchill) on which mitchilli (C. \& V.) was based. It is the same as a specimen with 10 anal rays (No. 718 A. M. N. H.) which was probably supposed to be the young of the Daddy Sculpin, groenlandicus, as it is in the same jar with a specimen of that species from Casco Bay, Maine, both labelled scorpiodes! This latter specimen of mitchilli is in good preservation. It has the back little elevated and the spinous dorsal a little higher than any aeneus examined,---its longest spine not quite half head. The colors are like those of Mr. Latham's specimen. An aeneus $4^{1 / 4}$ in., total length from Long Island with unusually high spinous dorsal has its longest spine 2.3 in head. No satisfactory structural difference, however, has been found between these two specimens of mitchilli, and aeneus. It is possible that recent authors are correct in synonimizing the forms but they look different.Ed.] 


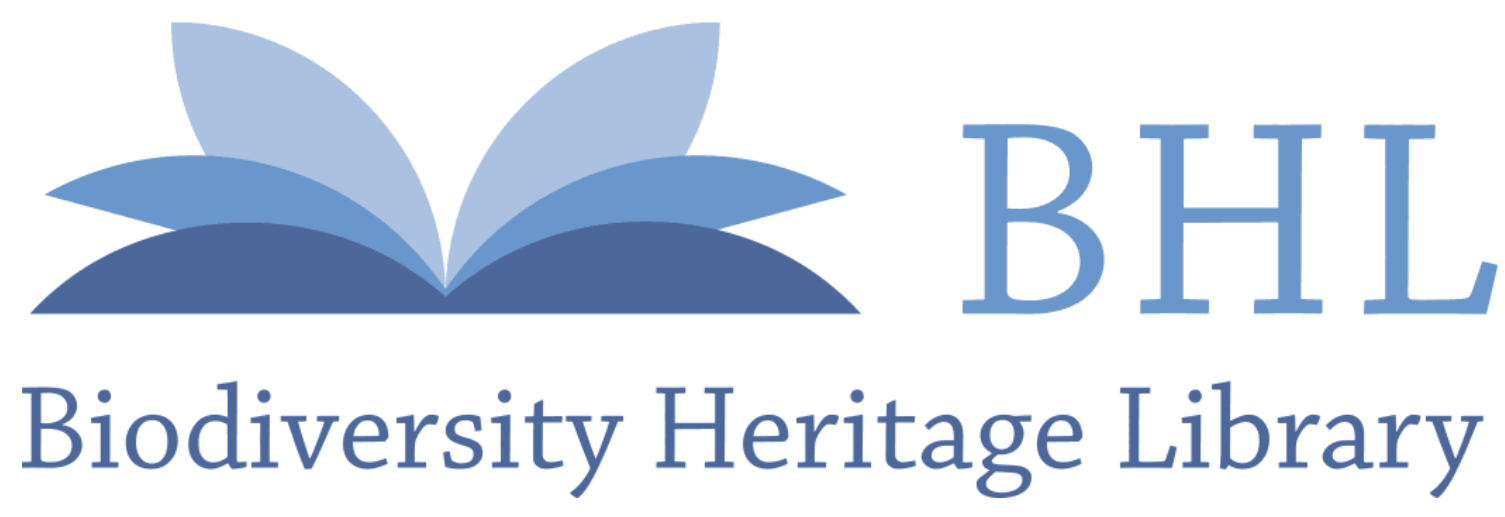

Latham, Roy. 1916. "Fish Records from Orient, Long Island." Copeia 31, 38-40.

View This Item Online: https://www.biodiversitylibrary.org/item/53398

Permalink: https://www.biodiversitylibrary.org/partpdf/85673

\section{Holding Institution}

Smithsonian Libraries

\section{Sponsored by}

Smithsonian

\section{Copyright \& Reuse}

Copyright Status: Public domain. The BHL considers that this work is no longer under copyright protection.

This document was created from content at the Biodiversity Heritage Library, the world's largest open access digital library for biodiversity literature and archives. Visit BHL at https://www.biodiversitylibrary.org. 